\title{
THE CONTINUED RELEVANCE OF BLACK LIBERATION THEOLOGY FOR DEMOCRATIC SOUTH AFRICA TODAY
}

\author{
RS Tshaka \\ Systematic Theology \& Theological Ethics \\ University of South Africa \\ $\&$ \\ MK Makofane \\ Christian Spirituality, Church History \& Missiology \\ University of South Africa
}

\begin{abstract}
Subsequent to the dawn of democracy in South Africa, many have surmised that to speak about Black Liberation Theology in such a context is not only irrelevant but challenges attempts at uniting South Africa. On the contrary, this paper argues that it is reckless to think that Black liberation theology must cease to exist merely because we had attained political freedom. It argues that Apartheid was systemic and had penetrated and influenced many institutions including economic institutions that are still operational in present day South Africa. It laments the fact that Black Liberation Theology did not adequately define the notion of freedom hence the confusion about the role of Black Liberation Theology today. It argues that our new struggle is the struggle for economic freedom and calls for Black Theology to seriously consider who its primary interlocutors are.
\end{abstract}

Key Words: Black Liberation Theology, Economy, Democracy, Black Elite, Apartheid

\section{Introduction}

The changed and changing situation in South Africa has posed significant challenges for the continued relevance of Black Liberation Theology since 1994. One such challenge has been the almost total disappearance of Black Theology from the South African socio-economic, political and cultural scene. This article will argue that Black Theology seem to be disappearing because the notion of liberation in Black Theology was not exhaustively problematized. It is for this very reason that this article insists that there is a significant differrence between Black Theology and a Black Theology of liberation. This will be explained in the article. When the notion Black Theology is used, it must be understood that reference is made to Black Theology of liberation.

Recognizing the peculiar position of a theological hermeneutic which was considered suspect during apartheid, this paper engages a new dispensation which ultimately befuddled even the greatest of black theological protagonists. It touches on issues of an elitist culture which was inevitable given the engineering of apartheid South Africa. It also engages the economy as well as the dearth of black theological voices with reference to a neoliberal economic bias which was adopted by the new managers of democratic South Africa. While it realizes that Black Liberation Theology is now more relevant than it was in the past, particularly given the growing black bourgeoisie, it remains very careful not to allow this 
conversation to degenerate into a class struggle. This is simply because this article is of the view that it is both racism and classism which gangs up against the most vulnerable in our society- the poor, the majority of which happens to be black. It is for this very reason that this article distinguish between the ontology which is unavoidable in Black Theology as well as the symbolism of Black Theology which encompass the entire human race. In the end a few comments are made with regard to the even more precarious position that scholars of Black Theology find themselves in today in South Africa.

\section{Tracing the Objectives of Black Liberation Theology in South Africa}

Already in the 1980s there were talks concerning the future role that Black Liberation Theology will play. In a paper read in 1984, Simon Maimela responded to these concerns by unapologetically stating that Black Theology as a theology of liberation was around to stay. ${ }^{1}$ He based his response then on his understanding of Black Theology and pointed out a significant aspect for our present understanding of Black Theology. He referred to the ontology of Black Theology which cannot be denied in any talk concerning this theology as well as the symbolism related to Black Theology. When used ontologically, black refers literally to certain people and is specific and therefore particular. As such it is confined to black people and their concerns. When used symbolically the word refers to "every human situation of enslavement, domination and oppression and therefore to the situation of deprivation, powerlessness and of being the underdog who suffer injustice at the hands of the powerful and the ruling elite'. ${ }^{2}$ Seen this way, it becomes clear that Maimela managed to address the universal without compromising the particular. This in our opinion is more acceptable instead of substituting Black Theology with contextual theology as was done with the dawn of democracy in South Africa.

The fact that Maimela brought the particularity and universality of Black Liberation Theology into a critical interplay is an encouragement for us who continue to believe that Black Liberation theology remains as relevant as it was during its inception. Maimela was prophetic when he argued that Black Liberation Theology will play an important role in the future because 'there will always be elements in the society who, for a variety of reasons, will feel themselves deprived, somehow oppressed and therefore in need of liberation, be it political, economic or socio-cultural'. 3 That he insisted on the 'Black' in Black liberation theology ${ }^{4}$ suggests that Maimela remained very aware of the fact that systems were intentionally designed to justify the second class citizenship of the darker people. It is this informed prophetical statement which forces us today to wrestle with Black Theology as a relevant theology for present day South Africa.

Black liberation theology emerged in South Africa during the late 1960s. As a project, it was inspired by the liberation theologies of Latin America, the civil rights movement in the USA, the prophetic voice of Martin Luther King Jr. as well as the pioneering work of James

\footnotetext{
S Maimela, 'Black Power and Black Theology in Southern Africa' in: Scriptura 12 (1984) 49.

S Maimela, 'Black Power and Black Theology in Southern Africa'. 48.

S Maimela, 'Black Power and Black Theology in Southern Africa'. 49.

Our insistence on the notion Black liberation theology is deliberate especially in a time where there seem to be a tolerance of Black Theology as long as its subjects remain invisible. There is widespread reference to Black Theology however as soon as the subjects of this theology claim their space, Black Theology becomes something that is best left in the past. With Dwight Hopkins we affirm Black Liberation theology which radically insists on God's preferential option to the poor in contradistinction to Black Theology as a vague enterprise 'which tends towards the maintenance of individual advancement with non-communal privileges'. Cf. D. Hopkins. Heart and Head: Black Theology, Past, Present and Future (New York: Palgrave, 2002), 161.
} 
Cone. It was transported from the shores of the United States of America to South Africa as an intellectual project which was made possible by the University Christian Movement (UCM) in 1971. All this occurred under the directorship of Basil Moore and was first spearheaded in South Africa by Sabelo Ntwasa.

In South Africa, Black liberation theology was expressed under the banner of the Black Consciousness Movement which owes its being to students such as Steve Biko, Barney Pityana, Harry Nengwenkulu and others who were galvanized by the then political situation into organising themselves into being a vanguard for the black peoples' total emancipation from the political pangs into which they were plunged by white racism in South Africa. It is perhaps fair to argue that the BCM was a black response to white liberalism. As the first president of this movement, Steve Bantu Biko led a breakaway from the National Union of South African Students (NUSAS) to form the all black student organization called South African Students Organization (SASO). ${ }^{5}$

It must also be stated that this move happened because Biko and others became aware of the fact that NUSAS, being a white liberal student organization, was not able to identify fully with the struggles of black people primarily because of the racial demarcations. Whites had a double standard, for they could claim to understand the struggle of black people, yet when confronted with the possibilities that negative sanctions might be applied to them upon identification with blacks, they would abandon the black cause. Woods argues that in response to the negative connotations that had been attributed to the black race, it was the philosophy of this movement to express group pride and determination by blacks to rise and realize their envisaged self. ${ }^{6}$

Goba suggests an examination of the socio-economic context shaping both these organizations, especially in the late 1960s, as one way of understanding the BCM and its relation to Black Theology. ${ }^{7}$ It is justified to say that both Black Consciousness and Black Theology are parallels, Black Theology being the theological response to the challenge of white theology. The BCM took race very seriously. It is obvious that without racial categorization, Black Consciousness might not have had reason to exist. Biko once maintained that the 'Black Consciousness' approach would be irrelevant in a homogeneous, non-exploitative egalitarian society, ${ }^{8}$ so we contend that Black Theology would have been irrelevant in a homogeneous non-exploitative, egalitarian society. West is in line with Biko when he argues that blackness has no meaning outside of a system of race-conscious people and practices. ${ }^{9}$ He concludes therefore that blackness is a political and ethical construct.

Although Black Theology propagated itself chiefly by means of seminars and ministers' caucuses, it produced some significant publications and continued into the Kairos period. ${ }^{10}$ A number of the first-generation black theologians endeavoured to develop Black Theology in relation to their confessional traditions. Among these theologians were Manas Buthelezi, Desmond Tutu, and Simon Maimela. This project was carried on by theologians such as

D Woods. Biko: The true story of the young South African martyr and his struggle to raise black consciousness (New York: Henry Holt Books, 1987), 150ff.

6 D Woods. Biko. 55.

7 B Goba, 'The Black Consciousness Movement: Its impact on Black theology' in: I Mosala and B Tlhagale (Eds.). The unquestionable right to be free: essays in Black Theology (Johannesburg; Skotaville Publishers, 1986), 61 .

8 Cf. S Biko, Black consciousness and the quest for a true humanity, in: B Moore (ed.). The challenge of Black theology in South Africa (Atlanta: John Knox Press, 1974), 36.

9 C West. Race Matters (New York: Vintage Books, 1994), 39.

10 Explain the Kairos moment. 
Buti Tlhagale, Takatso Mofokeng, Bongajalo Goba, Allan Boesak, Itumeleng Mosala, Mokgethi Motlhabi et al. ${ }^{11}$

For some black people, the God whom white people worshiped could not be the very God which they were worshiping. It was this realization that gave birth to Black Theology in South Africa. ${ }^{12}$ Tlhagale asserted that images of God as a just, loving and merciful Father did not correspond with the harsh reality of racism, landlessness, economic exploitation and political powerlessness. Nothing but Apartheid was to be blamed for the fact that Christianity (at least to the black populace) had become increasingly questionable. ${ }^{13}$

Apart from making the case that theology could not continue to ignore the socioeconomic and political aspects of this country, Black Theology wanted to discover how it could at the same time assert its blackness and remain truly acceptable within its mainline affiliation. This yearning is clearly illustrated in the works of many black theologians' chief of which is Allan Boesak ${ }^{14}$. Tlhagale has noted that the persistent use of the word 'black' to qualify a critical theological investigation drew much criticism from both black and white liberals, let alone the outright condemnation from the dominant Afrikaner group.

The charge, he continues, is that 'it perpetuates racism, distorts theological reflection and promotes a provincial mentality'. ${ }^{15}$ For Manas Buthelezi, Black Theology is nothing but a methodological formula whose genius consists in paying tribute to the fact that theological honesty cannot but recognize the particularity of the black man's [sic] situation. ${ }^{16}$ Black Theology, which is not without its shortcomings, is a direct and aggressive response to the situation where blacks encountered alienation at political, economic and cultural levels.

Black liberation theology is a realization, which stems from the reality of the black person - this is what we refer to as the particularity of Black Liberation Theology as suggested by Maimela. What this suggests is not that people from other races are excluded, however in South Africa during the Apartheid era; the mechanics needed to operate in black ion theology required that those engaged in it should be those whom the system of Apartheid was discriminating against and their reality could not be taken for granted.

For Cone the black reality could not be taken for granted by black people since "white people did everything within their power to define the black reality, to tell us who we were - and their definition, of course, extended no further than their social, political, and economic interest'. ${ }^{17}$ It was for this reason that the likes of Tlhagale were categorical in their opposition to the term 'contextual theology' for in their interpretation the concept remained an evasive expression in as far as it accommodated the self-justification of the oppressed group. ${ }^{18}$ Because of the involvement of white people in Black Theology, there

11 Cf. JW De Gruchy, 'African Theologies: South Africa' in: D Ford (ed.), The Modern Theologians. $2^{\text {nd }}$ edition (Massachusetts: Blackwell Publishers, 1997), 447.

12 See AA Boesak. Black Theology, Black Power (London: Mowbrays Publishers, 1976), 3.

13 B Tlhagale, 'Towards a Black Theology of labour' in: JR Cochrane and GO West (eds.) The Three-fold Cord: Theology, Work and Labour. (Cape Town: Cluster Publications, 1991), 143.

14 A Boesak. Black and Reformed: Apartheid, Liberation and the Calvinist tradition (New York: Orbis Books, 1984).

15 B Thagale, 'Towards a Black Theology of labour'. 142.

16 M Buthelezi, 'Black theology'. In: B Moore, (ed.). The challenge of Black theology in South Africa (Atlanta: John Knox Press, 1974), 34.

17 J Cone. God of the Oppressed. (Maryknoll, Orbis Books, 1997), 2.

18 B Tlhagale, 'Towards a Black Theology of labour' 142. 
seemed to be an overzealousness to emphasise the universal element of suffering intrinsic in Black Theology over the particular.

Thus the option of the concept 'contextual theology' to Black Theology by both some black and liberal white theologians needs to be understood against the background that many dreamt of a South Africa in which race would not dictate your standing in society. For Tlhagale it was impossible to negate Black Theology on these grounds because the 'black' in Black Theology substantiates the unique experience of the underdog. It is because of this unique experience that 'Black Theology differs in perspective, content, and style from the western theological tradition transmitted from Augustine to Barth, ${ }^{19}$

\section{The South African Economy, Democracy and Black Liberation Theology}

For a very long time, some have questioned the relevance of a Black Theology of Liberation in a democratic South Africa. This must be understood in the light of the 'guerrilla nature ${ }^{20}$ of Black Theology which was practised during apartheid. There can be no doubt that Black Theology was and remains marginalised both in the sill white controlled academy as well as black churches which continue to be economically dependent on the white mother churches. As a guerrilla initiative, Black Theology engaged critically the sources used by the dominant theologies but was never really accepted in the arenas that were white controlled. It asked critical questions with regard to the link between the Christian faiths confessed by the very people who justified an apartheid ideology. We shall return momentarily to the phenomenon of Black Theology as a guerrilla initiative.

For now, let it suffice to say that informed by the theology of James Cone and others, Black Theology of Liberation insisted on God's preferential option for the poor who are mostly the black populace of our country. This preferential option for the poor meant that Black Theology of liberation needed to denounce a white theology that was comfortable with its association with the elites in society. This suggests that the economy remains a very important aspect for the church and theology.

With regard to the South African economy it is imperative that we note that not much has been done with regard to Black Liberation theology and the economy of South Africa. Literature on this subject remains thus very scant. Very important and interesting analyses have been made with regard to land, labour and so forth. ${ }^{21}$ While it could be argued that these analyses addressed the issue of the economy, we cannot deny the fact that this only happened indirectly.

It is our opinion that critical analyses on this issue as well as other very important issues were prevented by the negotiations for a democratic South Africa. First it must be pointed out that apartheid seemed such an established reality that its official demise caught Black Liberation Theology in this country by surprise. Literature also indicates that the black

9 J Cone. God of the Oppressed. 3.

20 The best way to describe black Liberation theology in South Africa is to view it as a guerrilla initiative. From its very beginning Black Theology was considered dangerous to all peace loving Christians. In a context which was white controlled and where funding had conditions attached to it, there was no chance that Black Theology could compete on equal footing with a dominant theology to which Black Theology was providing an alternative. History has shown that while guerrilla initiatives are significant especially as these are the vanguard of the people, they are nonetheless susceptible to be abused by the very hegemonies against which they struggle. Perhaps by looking at Black Theology in this light we might come close to understanding its systematic evaporation from the South African scene.

21 B Tlhagale, 'Towards a Black Theology of labour'. 
political leadership was trumped on the economy during the negotiations for a democratic South Africa. ${ }^{22}$ Writing one of his best contributions to the economic debate in South Africa, Terreblanche argues that 'post apartheid South Africa has maintained a version of democratic capitalist system that is at best dysfunctional and fails to address the dismal legacy of inequality, imbalances and injustices accumulated during the first systemic periods of unfree labour'. ${ }^{23}$ It is furthermore also our view that the notion democracy is used to stifle arguments that questions the continued sorry state of the majority of South Africans.

Democracy is hailed as one of the greatest achievements of man and in South Africa in particular it is used to eschew any talk that evokes past injustices. Because democracy is seen as man's greatest achievement, there is no intentional and deliberate attempt to question what is accepted as democratic practices even in situations where serious questions must be raised with regard to the citizenship of many who continue to exist on the fringes of society. Democracy must be seen as the embodiment of Thomas Hobbes' Leviathian to which we have readily surrendered our freedom to think for ourselves. ${ }^{24}$ The likes of Sampie Terreblanche, Noam Chomsky and others understand this quite too well. It is therefore not by chance that Terreblanche argues that 'the logic of democracy and capitalism is contradictory'. He explains, 'while democracy emphasizes joint interests, equality and common loyalties, capitalism is based on self-seeking inequality and conflicting individual and group interests'. ${ }^{25}$ What is more important, notes Terreblanche, is that 'the legal system that protects both democracy and capitalism is based on the principle of equality before the law, but maintains inequality in the distribution of property rights and opportunities in the capitalist system'. For him the logic of capitalism - given the unequal freedoms and unequal rights upon which it is based goes against the grain of the logic of democracy.

This depiction of democracy comes very close to Noam Chomsky's depiction of the subject. Chomsky argues that democracies at best envision the common masses as people who are incapable of thinking for themselves. He refers to the American Walter Lippmann, a major foreign and domestic critic and also a major theorist of liberal democracy. Lippmann who was involved in propaganda commissions in the USA argued that what he called a 'revolution in the art of democracy' could be used to 'manufacture consent'. ${ }^{26}$

Manufacturing consent was important for Lippmann because as he puts it, 'the common interests elude public opinion entirely'. Society is thus divided between the small minority elite and the majority who are best left with the least information since knowledge in itself is considered dangerous for them. The masses are therefore supposed to be mere spectators and not active participants in democracy although they are from time to time allowed to

22 Cf. WM Gumede. Thabo Mbeki and the Battle for the Soul of the ANC (London: Zed Books, 2007), 79ff; S Terreblanche. A History of inequality in South Africa: 1652-2002 (Pietermaritzburg: University of Natal Press, 2002).

23 S Terreblanche. A History of inequality. 17.

24 The notion 'Leviathan' was made popular by Thomas Hobbes in his 1651 piece. In his attempt to answer the question 'who' and 'what' Leviathan is, Hobbes asserts that Leviathan is the epitome of the rise and existence, the past, present and future, the essence and reality or state as the only earthly potentate and sovereign with one or more heads. People have handed over and entrusted to it all their political, social, economic, intellectual, and even ethical and religious freedoms, possibilities and rights. By their consent Leviathan is safeguarded against every possible protest, thus he rules in their place over them. T. Hobbes. Leviathan (Oxford: Oxford University Press, 2008).

25 S Terreblanche. A History of inequality. 16.

26 N Chomsky. Media Control: The Spectacular achievement of propaganda. $2^{\text {nd }}$ edition. (Kindle edition: November 30, 1991), 22. 
lend some weight by voting for this or that leader and then immediately retreat to being spectators of the game.

Lippmann argued that the masses are a 'bewildered herd' and are therefore considered too stupid to be able to understand things. The instrument that is used to tame this bewildered herd so that they do not trample and destroy things is called democracy. ${ }^{27}$ This is very close to Jeremy Cronin's summary of the then Mbeki government. He argued that the approach of the Mbeki government to the concerns of the masses can be summarized as, "we are now in power on your behalf. Take a back seat, we will make the decisions and deliver. Mass mobilization such as strikes, protests and questioning of the leadership's authority gets in the way of your government doing the job. In any case, we have a plan, it may be slow, but be patient". ${ }^{2}$ The fact that the masses are continuesly seen as the bewildered herd which needs to be tamed raises questions of the present regime which still does not seem to have the will power to make dramatic changes to the economic disparity of South Africans.

Apartheid was a system that called into question the citizenship of blacks in South Africa. When one consider the socio-economic position of this very people today, one clearly get a sense that an old system clothed in new garment continues what colonilization and apartheid started. In speaking of systems, Terreblanche refers to Max Weber's consideration of a system. For Weber a system is a three-dimensional social fabric or an equivalent tetrahedron - a three sided pyramid with a political, socio-economic and ideological side. A power shift from one system to another does not only question and undermine the legitimacy of each of the three sides of the Weberian pyramid, but is only completed when a new power constellation has been established, with a reasonable level of agreement between the new elite groups on each of the three sides of the pyramid. Thus if the new system and new power constellation prove to be dysfunctional and does not serve the interests of all the subgroups in society, the stability and sustainability of the new system will be threatened. ${ }^{29}$

The new system which is a result of the new alliances between the most powerful who control the corporate sector and the black political leadership is yet to prove its functionality given the growing gap between the rich and the poor. Terreblanche is correct when he argues that while the poor and therefore the majority of the citizens who are black are at the receiving end of unemployment, poverty, inequality, violence and criminality, these elements have an indisputable structural or systemic character. ${ }^{30}$ All of these problems have been shaped and created over a very long period by the power structures of which the system of colonialism, segregation and apartheid were based. He continues to ask a profound question as he evaluates the economic disparity in democratic South Africa. His question is why has the conditions of the poor not changed since 1994? For Patrick Bond this question is clear and to the point. South Africa has witnessed nothing but an elite transition. ${ }^{31}$ The answers of Terreblanche to this question are worth noting. For Terreblanche it is crucial that we firstly concentrate on the nature of poverty and unemployment or the nature of the

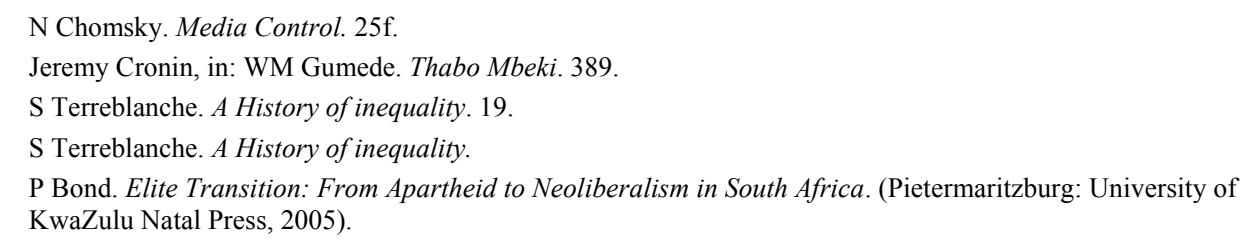


remnants of systemic exploitation and secondly that we focus on the inadequacy of the new government's economic and social policies.

In dealing with the first focus, he asserts that 'the powerful corporate sector forced the new government into accepting a neo-liberal and global oriented economic policy for the new South Africa and this excluded the possibility of comprehensive redistributive measures. ${ }^{32}$ He continues to argue that in addition to the many elite compromises that were negotiated between the corporate sector and the ANC, an economic system has been institutionalized which systemically excludes the poorer half of the population from mainstream economic and political activity. This is reminiscent of what Fanon observed. Frantz Fanon reminded us of a fundamental aspects which is often ignored when a political situation has underwent some change. He argues that 'the colony's economy is not integrated into that of the nation as a whole. It is still organized in order to complete the economy of the different mother countries'. ${ }^{33}$ This is true also of present day South Africa where the economy continues to be controlled by those who benefitted from the apartheid engineering system. The most interesting thing to note here is the similarity between how the black political leadership was outsmarted by the charm of the corporate sector and the systematic evaporation of a once vibrant Black Theology. This evaporation was brought about by a new dispensation which was in reality controlled by the true yielders of power - the corporate sector.

There can be no doubt that the ANC was outsmarted by the corporate sector with the informal economic negotiations. ${ }^{34}$ The reasons for this are manifold. Gumede reckons that they range from the ANC's rudimentary understanding of how the economy works to the softening of staunch ANC leaders through the means of wining and dining them. The corporate sector played a significant role in this regard. However, it did much more than this; it also inculcated an unsympathetic attitude in the middle class about the poor. It is vital that we consider this attitude especially in a country pregnant with contradictions such as South Africa. Reminiscent of colonization with its tendency to patronize the natives, Terreblanche points to the perpetual inclination of the powerful to seek justification for why they can continue to enjoy their extravagant lifestyles in the midst of abject poverty. It is this very attitude, he concedes which can function as a very impressive tool to engineer and justify divisions among people.

The attitudes of the rich and powerful towards the poor is significant in another sense, it determines the degree of assistance that the poor could get from them. ${ }^{35}$ As a means of insulating themselves from the reality of structural poverty, these elite groups subscribe poverty to the flaws and shortcomings in the character and personality of the impoverished individuals and or their racial status. ${ }^{36}$ For a very long time 'members of the white elite had often emphasized the virtues of a middle class work ethic, and placed a high value on the importance of individual initiative and achievement'. ${ }^{37}$ By subscribing to this perspective,

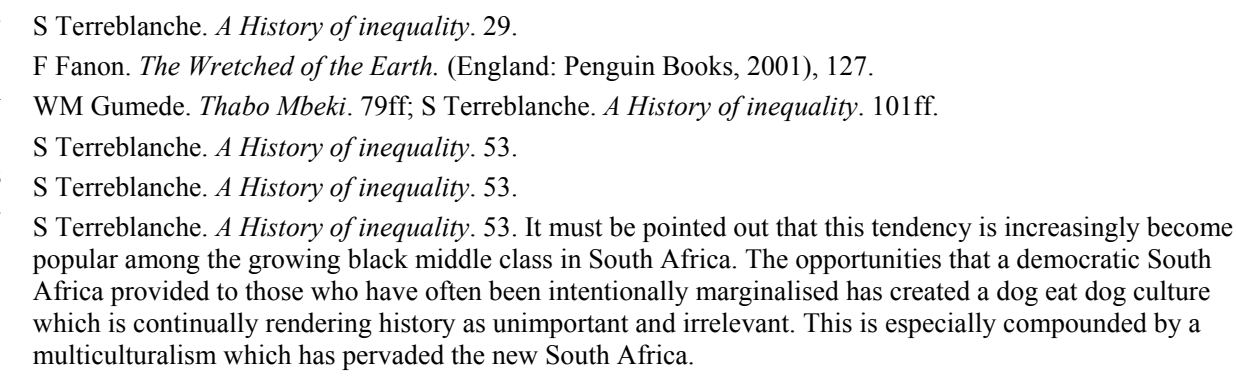


the link of poverty to structural factors is intentionally ignored and rendered unimportant. It is therefore not by chance that the structural explanation of poverty has not yet enjoyed its deserved attention in South Africa.

Terreblanche reminds us that the South African corporate sector has certain unique distinguishing features which has always worked in its favour in the past and continues to do so even today. These features, he argues, are concentrated in the hands of a small number of mega corporations with formidable financial, organizational, ideological and even political power. What is most interesting about the South African corporate sector is its strong propensity for myth making and propagandizing in order to legitimize its power and privilege, and alleged functionality in promoting the interests of all South Africans. ${ }^{38} \mathrm{He}$ argues that 'the corporate sector's propaganda has (and still is) disseminated with great sophistication and conviction and the mining and or mainstream media has played and is still playing a strategic role in doing so, ${ }^{39}$

There are two main categories of ideologies or myths propagated by South Africa's corporate sector to legitimize itself as outlined by Terreblanche. The first has to do with the alleged capacity of the liberal (or free market) capitalist system to promote the interests of the total population irrespective of whether or not the economic system in South Africa can credibly be described as such. Second, is the contention that a high economic growth rate in South Africa will -despite deeply institutionalized inequalities - automatically 'trickle down' to the poor. ${ }^{40}$ Let us now briefly consider the concrete situation of the majority of black people in South Africa and the significance of a Black Theology of liberation.

\section{The Concrete Situation of Blacks as a Means of Avoiding an Amorphous Black Theology}

No one has defined Black Liberation Theology more correctly than Cone himself. For him, 'Black Theology is a theology of and for black people, an examination of their stories, tales and sayings'. He continues to argue that 'for theology to be black, it must reflect upon what it means to be black. Black theology must uncover the structures and forms of the black experience, because the categories of interpretation must arise out of the thought forms of the black experience itself ${ }^{41}$ This is what black theologians in South Africa understood and yet struggled to inculcate in black communities since Black Theology was seen as too radical and empowering black people to question their state of affairs. This meant at best that the black theological project could only exist as a guerrilla initiative as observed earlier in this paper.

One of the objectives of Black Consciousness (as was indicated above) was to devise ways of informing black people about the evil of Apartheid and bringing about authentic liberation. Goba is correct when he suggests that Black Consciousness is political in the sense that it identifies white oppressive socio-economic structures. ${ }^{42}$ This is the concrete situation of black which Black Liberation Theology must take very seriously. To be able to embrace Black Consciousness as an attitude of life is no easy task. Biko once lamented the cowardice of black people for not living up to the expectations of this philosophy. In the

38 S Terreblanche. A History of inequality. 55.

9 S Terreblanche. A History of inequality. 55.

$40 \mathrm{~S}$ Terreblanche. A History of inequality. 56.

41 J Cone. God of the Oppressed. 16-17.

42 B Goba, The Black Consciousness Movement' 66. 
collected writings, Frank talk written initially under a pseudonym, Biko lambasted blacks for cursing whites and their oppressive tactics while there were no whites around. $\mathrm{He}$ writes, 'they [blacks] stand united in their anger and disdain for the white man when they are all together, returning to their dilapidated houses, yet when they are suddenly confronted by a police, curses turn into words of praises for what the whites are doing for the little black people'. ${ }^{43}$

On the one hand Black Theology (and for that matter Black Consciousness) must be credited for helping to instil a sense of self-worth into black people. We cannot deny that the economic discrepancies that still exist between black and white, however a Black Consciousness which is aimed at developing a positive sense of the black self without seriously considering the economic element which bends blacks to the will of their white masters proves to be impotent to the most vulnerable. There can be no doubt that the issue of the economy of the country has not enjoyed much attention in much of the black theological reflections of the past. It remains as significant today particularly in the wake of the growing black middle class.

Goba rejects the speculation that Black Theology and therefore Black Consciousness was only something existing within the black middle class. In 1986, he argued that 'to speak about a pocket of the emerging black bourgeois class was to create confusion in the minds of our people. Because [in his opinion] as far as the average black person is concerned the black middle class is part and parcel of the oppressive socio-political status quo in this country'. ${ }^{44}$ While Goba's concern must be heeded in the light of the general struggle of the black populace, we must nonetheless seriously consider the question of why Black Theology did not managed to percolate black communities profoundly.

A number of reasons can be cited which prevented this profound percolation of Black Theology in black communities. Chief among these is the dependency of many black communities on a white controlled economy and the gravitation of the proponents of Black Theology to key positions of administration in the new government. While the likes of Cone and others could reflect on Black Liberation Theology beyond the Civil Rights movement of the USA, the new democratic dispensation opened opportunities for many proponents of Black Theology. This resulted in the fumbling of an already struggling new academic discipline.

Mosala has criticised Black Theology for the very reason that we have alluded to when he asserted that 'it cannot be contested that although Black Theology has developed and is well and live [sic], it has not yet, as a weapon of theory, become the property of the struggling black masses. To this extent, it is a theory that has not yet become a material force because it has not gripped the masses. It has served its purpose well as a weapon of criticism against white theology and the white society. That activity, however, does not replace criticism of the weapon itself. ${ }^{45}$ One succinct point must be made in response to this view projected by Tlhagale. Firstly, it reflects the perception that the advocates for Black Theology and Black Consciousness did not think beyond the primary goal which was for black people to attain political liberty in this country. Confused by the new dispensation and enthralled by incentives given to the leadership of the vanguard, many proponents of Black Theology became gradually convinced that perhaps Black Theology had finally

43 S Biko. I write what I like. (San Francisco: Harper and Row Publishers, 1972).

44 B Goba. The Black Consciousness Movement. 66.

45 Cf. I Mosala, 'The use of the Bible in Black theology' in: I Mosala and B Tlhagale. The unquestionable right to be free: Essays in Black Theology. (Johannesburg: Skotaville Publishers, 1986), 176. 
reached the end of its lifespan. This problem can only arise as Hopkins once observed when the liberation of the poor is dropped from Black Theology. ${ }^{46}$

The economic dependency of the majority on the minority is another reason why Black Theology failed to grip the masses. It was this very economic dependency which had encouraged the masses to put on personas in order to survive in white South Africa. While the critique of Biko which speaks to this change of personas is important in that it is at pains with the African who must become a man and stop being a shadow of a man, it remains a reality for many blacks even today. In essence, what we are trying to say here is that Black Consciousness becomes relevant only within a particular context. It takes form in a context were black is no more dependent on white for survival. This has to do therefore with economic power and not necessarily only political power.

Reminiscing about the origins of Black Theology in the USA, Cone reflects on three fundamental situations which are imperative to our purpose here. The first relates to the 1950s and 1960s and is largely associated with Martin Luther King Jr; the second refers to the work of Joseph Washington - an African American who wrote the book 'Black Religion'. The last refers to the rise of Black Power Movement and is strongly influenced by Malcolm X's philosophy of Black Nationalism. ${ }^{47}$

While some aspects in the first and last contexts which he describes might perhaps be commonly known, there is a significant aspect which he raises and might not have receive the necessary attention by those who appropriated Black Theology for South Africa. Cone is adamant in arguing that 'because blacks received little or no theological support from white churches and their theologians (who were preoccupied with Barth, Bultmann and the death-of-God controversy!), blacks themselves had to search deeply into their own history in order to find a theological basis for their prior political commitment to liberate the black poor'. ${ }^{48}$

Thus they found such support in the likes of Richard Allen - founder of the African Methodist Episcopal Church, as well as the likes of Henry Highland Garnet, Henry McNeal Turner and others. Black mainline churches were very much influenced by theologies which had their origins elsewhere to the black experience. ${ }^{49}$ The process of assimilation which remained central in the conversion of many Africans to this faith Africa did not leave much room for African cultures and world views to be integrated with this faith. ${ }^{50} \mathrm{We}$ shall now turn to consider additional elements which must be taken seriously by a Black Theology of liberation in present day South Africa.

46 D Hopkins. Heart and Head. 162.

47 J Cone. For my People: Black theology and the Black Church (Maryknoll: Orbis Books, 1984), 6-11.

48 J Cone. For my People. 7.

49 Very similarly to the USA situation, black expressions of the faith in South Africa were always seen as unsavory. Thus when the African American Joseph Washington contended that black religion exists because blacks have been excluded from the faith of the white churches and therefore that black churches are not genuine churches and consequently had no Christian theology, such news was received very well by white Christians. Instead of accepting the charge that theirs is simply folk religion, black Christians vehemently rejected Washington's claim that exclusion from white churches and seminaries also meant exclusion from the spiritual and theological riches of the biblical faith. Cf. J Cone. For my People. 9. In South Africa the need to be different and at least better than the rest saw many black Christians within the mainline church traditions succumbing to these the lies that characterized some black churches as not being genuine churches. Instead of looking deeper into their origins, you had many Christians in the mainline church tradition seriously struggling to be assimilated into the so called mother churches with disastrous repercussions.

50 Cf. RS Tshaka. 'African you are on your own! The need for African Reformed Christians to seriously engage their Africanity in their Reformed Theological reflection’. In: Scriptura Vol 96 (2007:3), 533-550. 


\section{More Challenges Facing Black Theology of Liberation in South Africa Today}

In this section we will briefly focus on additional challenges facing Black liberation theology in South Africa. There are clearly many challenges, however due to scope of this paper is impossible to deal with all these challenges fairly. For the purpose of our paper we have identified two challenges namely; a new paradigm as well as the elitist character of Black Theology. This is the prism through which we look at the challenges facing Black Theology in present day South Africa.

\section{New Paradigm}

Maluleke points out that the most fundamental challenge that has faced Black Theology in the past decade originates in the socio-political atmosphere. ${ }^{51}$ In a similar vein, Maimela argues that Black Theology of liberation in South Africa was characterized by its emphasis on the struggle for the socio-economic and political liberation from white racial domination. ${ }^{52}$ The liberation dimension of Black Theology in the past tended to focus on racism and rightly so since apartheid was overtly sanctioned by law in South Africa. In other words, the number one enemy of Black Theology obvious in this instance was racism.

While scholars such as Mugambi in his famous book (From liberation to Reconstruction: African Christian Theology after the Cold War, 1995) suggest a move from 'liberative metaphor' to a new paradigm of 'theology of reconstruction' we are still operating with the liberation paradigm but seeking to expand its scope. ${ }^{53}$ The demise of apartheid requires for the liberation dimension of South African Black Theology to broaden its scope (in the sense of being engaged in the struggle for liberation from the contemporary causes of human suffering such as oppression of women, corruption by government officials, class issues, HIV/Aids, poverty, Xenophobia, Third World debt etc.).

For instance, recently a spate of non-delivery protests by black poor has rocked our country. The present government has employed the old violent military tactics of the Apartheid regime to crush such protest. The irony is that it is a democratic government of black people meting out violence to their very own. The present administration is now colluding against its own people, creating and perpetuating the injustices, oppression and exploitations which are devastating for black poor. This state of affairs warrants critical and prophetic participation of black theologians and other critical structures as Motlhabi has reminded us. ${ }^{54}$ However the silence of black theologians is conspicuous to say the least. One is not sure whether the lull has to do with 'critical solidarity with the state' stance which was adopted by church leaders immediately after the official and legal demise of apartheid. Motlhabi has rightly noted that 'critical solidarity' is dangerous if allowed to degenerate into a blind and uncritical following the state in everything. ${ }^{55}$

If Black Theology is to survive and remain relevant for South Africa today, it would seem to us that it must encompass broader issues of social justice rather than focussing solely on matters of racial justice although race is not to be ignored or minimised since it

51 T Maluleke. Tutorial Letter/102/98 for MSB301-F (Unisa, 1998, 87).

52 S Maimela. Culture, Religion and Liberation. Proceedings of the EATWOT Pan African Theological, Conference (Nairobi: AACC, 1994, vii).

53 JNK Mugambi. From Liberation of Africa: Toward a Theology of Reconstruction (Nairobi: AACC, 1995)

54 MBG Motlhabi. African theology/ Black Theology in South Africa: Looking Back, Moving On (Unisa: Unisa Press, 2008, x).

55 MGB Motlhabi. African Theology/Black Theology in South Africa. x. 
remains a significant factor today. Therefore Black Theology of liberation has to broaden its scope without denying the fact that structures [especially economic] keep the majority in the dilapidated state that they are currently in. The majority clearly continues to be black. With this we concede to the fact that while apartheid has been abolished legally, racism continues to exist in democratic South Africa. The country continues to suffer the effects of Apartheid and its scars are glaring for everyone to see. Black theologians must continue to confront the results of this monster, however equally important, Black Theology must undergo what Motlhabi calls 'reorientation and readjustment' in its approach to new developments in, and changed problems of, the new South Africa. ${ }^{56}$

\section{Elitist Character of Black Theology}

The fact that we can construe Black Theology as a guerrilla initiative does not suggest that it was void of elitism. In fact when one considers the history of education in South Africa and ponders the role that education had to play for those who engineered power as well as the subjects of power one clearly gets a sense that from its very inception, education was meant to pit one against the other. The Verwoerdian perception of education for the natives is particularly important if we want to understand an elitist culture to which blacks were susceptible to. The apartheid Minister of education Hendrik Verwoerd once said the following with regard to education for black people in South Africa, "education must train and teach in accordance with their opportunities in life, according to the sphere in which they live Education should have roots entirely in the Native areas and in the Native environment and Native community in all aspects. There is no place for him in the European community above the level of certain forms of labour". ${ }^{77}$

The fact is that Black Theology as an academic discipline [albeit considered very suspect by the white academic hegemonies] was by its very nature an elitist enterprise particularly during its elementary stages until it went to what Mothabi calls 'recess ${ }^{58}$ Even though it drew a sizeable number of black ministers from various church denominations it was the local academic base that spread its message through conferences and publications albeit this base did not enjoy the full support of the still white controlled academia. It is important that we remember Black Theology as a guerrilla initiative but also what happened to it with the dawn of democracy. When many veteran black theologians left academic work in droves to take up various administrative positions in various sectors there was a certain degree of intellectual retreat. The elitist nature of Black Theology is further revealed in Journal of Black Theology in South Africa, whereby the subscribers of the journal were largely staff and students in seminaries and universities and moreover it was accessible only in English not other African languages.

One has to acknowledge the role played by black caucus groups in some mainline churches such as Black Methodist Consultation and Belydende Kring (BK) in the former Dutch Reformed Church in Africa but there was always as Maluleke has rightly pointed out an element of ambivalence towards Black Theology. ${ }^{59}$ It is against this background Mosala has concluded that Black Theology has not yet, as a weapon of theory become the property

56 MGB Motlhabi. African Theology/ Black Theology in South Africa. 15.

57 RS Tshaka. Confessional Theology? A Critical Analysis of the Theology of Karl Barth and its Significance for the Belhar Confession. (Unpublished DTh dissertation. University of Stellenbosch, 2005), 224.

58 MBG Motlhabi. African Theology/Black Theology in South Africa. $x$.

59 T Maluleke. Tutorial Letter/102/98 for MSB301-F (Unisa, 1998), 89. 
of the struggling masses who are also found in our churches. ${ }^{60}$ In other words, the black church masses have not really have a sense of ownership of Black Theology. This is as Hopkins has observed, because 'black theologians are yet to write so their families, communities and descendants can understand their roles as the poor of the poor in history. ${ }^{61}$

\section{From Guerrilla Initiative to a Spot in the Shade of White Hegemonies: Conclusion}

The problem with guerrilla initiatives is that they are usually susceptible to the seduction of power. Thus it remains vital that such initiatives wrestle seriously with the very objectives which called them into existence. It has been argued elsewhere that that the easiest way of killing a revolution is to hire out from the leadership of that revolution. ${ }^{62}$ This hiring out has certainly occurred in diverse ways. One such way is to invite leaders of these guerrilla initiatives to be part of the mainstream. This needs to be said acknowledging the fact that the current generation of black theological scholars stand on the shoulders of those who preceded them. It is thus very important to concede to these challenges as we are pressured to comply with the expectations of the academe. It must also be pointed out that the very academe remains still very white in South Africa, with epistemologies and methodologies for engaging in scholarship which at best remain foreign to the majority. This is thanks to the legacies of colonialisation and apartheid.

Hopkins has warned against the spot given to initiatives such as Black Theology of liberation in the mainstream. He argues that it is the pressure of the academe which might lead us to feel the need to dispense with black intellectual experiences of the poor. ${ }^{63}$ This is particularly important given the fact that racism continues to prevail albeit in a more nuanced and sophisticated manner. This is evidenced by the economic and political structures which have remained virtually unchanged. Remembering the objectives of Black Theology can only be important if we are to insist with the Christian gospel in identifying with the poor and marginalised in society. It is this pro-poor position, according to Hopkins, which will sharpen the distinction between a Black Theology of liberation which encourages a gospel of good news for all broken humanity and a vague Black Theology - which tends toward the maintenance of individual advance and non-communal privileges. ${ }^{64}$ It seems to us that given the current situation, Black Theology of liberation remains as relevant as it was with its inception.

60 Cf. I Mosala, 'The use of the Bible in Black Theology' in: I Mosala and B Tlhagale. The unquestionable right to be free: Essays in Black theology. Johannesburg: Skotaville Publishers, 1986. 176.

61 D Hopkins. Heart and Head. 166.

62 Cf. RS Tshaka, 'The dilemma of ethical leadership in present day South Africa'. In: Missionalia 37:2 (August 2009), pp. 153-164.

63 D Hopkins. Heart and Head. 160.

64 D Hopkins. Heart and Head. 161. 


\section{BIBLIOGRAPHY}

Biko, S 1972. I write what I like. San Francisco: Harper and Row Publishers.

Boesak, A 1984. Black and Reformed: Apartheid, Liberation and the Calvinist Tradition. New York: Orbis Books.

Bond, P 2005. Elite Transition: From Apartheid to Neoliberalism in South Africa. Pietermaritzburg: University of KwaZulu Natal Press.

Chomsky, N 1991. Media Control: The Spectacular achievement of propaganda. $2^{\text {nd }}$ edition. Kindle edition. November 30, 1991.

Cochrane, JR and West, GO (eds.) 1991. The Three-fold Cord: Theology, Work and Labour. Cape Town: Cluster Publications.

Cone, J 1984. For my People: Black theology and the Black Church. Maryknoll: Orbis Books.

Cone, J 1997. God of the Oppressed. Maryknoll, Orbis Books.

Fanon, F 2001. The Wretched of the Earth. England: Penguin Books, 2001.

Ford, D (ed.) 2001. The Modern Theologians. $2^{\text {nd }}$ edition. Massachusetts: Blackwell Publishers.

Gumede, WM 2007. Thabo Mbeki and the Battle for the Soul of the ANC. London: Zed Books.

Hobbes, T 2008. Leviathan. Oxford: Oxford University Press.

Hopkins, D 2002. Heart and Head: Black Theology, Past, Present and Future. New York: Palgrave.

Maimela, S 1984. 'Black Power and Black Theology in Southern Africa' in: Scriptura 12 (1984).

Maimela, S 1994. Culture, Religion and Liberation. Proceedings of the EATWOT Pan African Theological, Conference. Nairobi: AACC.

Maluleke, T 1998. Tutorial Letter/102/98 for MSB301-F (Unisa, 1998).

Moore, B (ed.) 1974. The challenge of Black theology in South Africa. Atlanta: John Knox Press.

Mugambi, JNK 1995. From Liberation of Africa: Toward a Theology of Reconstruction. Nairobi: AACC.

Motlhabi, MBG 2008. African theology/Black Theology in South Africa: Looking Back, Moving On. Mucleneuk: Unisa Press.

Terreblanche, S 2002. A History of inequality in South Africa: 1652-2002. Pietermaritzburg: University of Natal Press.

Tshaka, RS 2009. 'The dilemma of ethical leadership in present day South Africa'. In: Missionalia 37:2 (August 2009), pp. 153-164.

Tshaka, RS 2005. Confessional Theology? A Critical Analysis of the Theology of Karl Barth and its Significance for the Belhar Confession. Unpublished DTh dissertation. University of Stellenbosch.

Mosala, I and Tlhagale, B (eds.) 1986. The unquestionable right to be free: Essays in Black theology. (Johannesburg: Skotaville Publishers.

Woods, D 1987. Biko: The true story of the young South African martyr and his struggle to raise black consciousness. New York: Henry Holt Books. 